\title{
Repairing peripheral nerve defects by vein grafts filled with adipose tissue derived stromal vascular fraction: an experimental study in rats
}

\author{
Heval Selman Özkan, M.D., ${ }^{1}$ Özlem Karataş Silistreli, M.D., ${ }^{2}$ Bekir Ergür, M.D., ${ }^{3}$ Saime İrkören, M.D. ${ }^{1}$ \\ 1'Department of Plastic and Reconstructive Surgery, Adnan Menderes University Faculty of Medicine, Aydın, Turkey \\ 2Department of Plastic and Reconstructive Surgery, İmir Atatürk Training and Research Hospital, Izmir, Turkey \\ ${ }^{3}$ Department of Embriology and Histology, Dokuz Eylül University Faculty of Medicine, İzmir, Turkey
}

\begin{abstract}
BACKGROUND: There are many studies in the literature combining vein grafts with cell cultures, muscle, tendon, and nerve tissues, but none of them could replace isolated nerve grafts for nerve repair in clinical settings. There are studies in the literature indicating that adipose tissue derived stromal vascular fraction (SVF) enhances peripheral nerve healing. Considering these facts, an experimental study was performed in rats based on combining SVF with vein grafts for peripheral nerve defect repairs.
\end{abstract}

METHODS: The study included 30 rats which were divided in three groups. In the first stage, an 8 mm nerve defect was created in tibial nerve of each rat. In Group I, the defect was reconstructed with nerve graft, in Group 2, the defect was reconstructed with vein graft, and in Group 3, the defect was reconstructed with vein graft filled with SVF solution. After 3 months, the second surgical stage was performed and nerve biopsies were taken. Tissue samples were observed histopathologically.

RESULTS: There were no statistically meaningful difference between nerve grafts, vein grafts and adipose tissue derived SVF- vein grafts combination groups considering myelin diameter and axonal diameter. Axon count was statistically superior in the nerve graft and study groups when compared to empty vein groups.

CONCLUSION: In conclusion, our results support the usage of stromal vascular fraction-vein graft combination for peripheral nerve defect repairs.

Key words: Adipose tissue; nerve defect; stromal vascular fraction; vein graft.

\section{INTRODUCTION}

Proper end-to-end nerve repair is the treatment of choice in the reconstruction of peripheral nerve injuries. In some clinical situations, there is not a sufficient portion of a nerve present to perform an end to end nerve repair. ${ }^{[1,2]}$ Autogenous nerve grafting has been the standard technique for repairing these conditions of nerve defects. The results are satisfactory, but this technique causes significant nerve graft

Address for correspondence: Saime İrkören, M.D.

Adnan Menderes Üniversitesi Tıp Fakültesi, Plastik ve Rekonstrüktif Cerrahi Anabilim Dalı, 09100 Aydın, Turkey

Tel: +90 256 - 2441240 E-mail: saimeirkoren@hotmail.com

Qucik Response Code Ulus Travma Acil Cerrahi Derg

2016:22(I):7-II
doi: $10.5505 /$ tjtes.2015.126I2

Copyright 2016

TJTES donor site morbidities such as scarring, neuroma formation, and loss of sensation. Many treatment modalities have been looked intoto overcome this problem. Vein and muscle-filled vein grafts have been reported as alternatives to the classical nerve grafting. ${ }^{[3-5]}$ There are some experimental and clinical studies using conduits, growth factors and stem cells for the repair of nerve defects. ${ }^{[6-8]}$

Stem cells, because of their pluripotentiality and unlimited capacity for self-renewal, are expected to allow significant advances in distinct reconstructive procedures. Currently, scientific and clinical interest is high regarding the potential of stem cells to treat a broad range of conditions. Many sources of stem cells have been identified, including bone marrow, fat, muscle, liver, skin, heart, and brain in adults in addition to fetal and embryonic sources. Adipose-derived stem cells can be easily processed from lipoaspirated or extracted fat and provide a significant quantity of multipotent stem cells for a variety of therapeutic conditions. ${ }^{[9,10]}$ Stromal vascular fraction is an easily prepared solution obtained from lipoaspirate which includes signicant number of adipose derived stem cells. Many 
recent studies in the literature indicate that adipose tissue derived stem cells can stimulate nerve regeneration by both undergoing neural differentiation and through the release of a range of growth factors. ${ }^{\left[{ }^{\prime \prime}\right]}$ The purpose of this experimental study was to evaluate the effectiveness of vein grafts filled with adipose tissue derived stromal vascular fraction for the repair of nerve defects, and to compare it with empty vein grafts and nerve grafts.

\section{MATERIALS AND METHODS}

Thirty Wistar adult male rats weighing 250-300 g were used in this study. Approval for this study was obtained from the Local Animal Care and Ethics Committee. All animals were fed with rat chow and water ad libitum. Under anesthesia with intraperitoneal $100 \mathrm{mg} / \mathrm{kg}$ ketamine and $15 \mathrm{mg} / \mathrm{kg}$ xylasine injection, the animals were operated on following surgical procedures described below. All surgical procedures were performed with the aid of an operating microscope.

Three major fascicles of the sciatic nerve were exposed by a gluteal muscle splitting incision, and an $8 \mathrm{~mm}$ long nerve gap was created by sectioning a nerve segment from the distal part of the tibial nerve. Three groups, containing ten rats each, were created according to the technique used for filling the nerve gap (Figs la, b).

\section{Group 1 (Nerve Graft Group)}

At both sides, three major fascicles of the sciatic nerves were exposed by a gluteal muscle-splitting incision and separated by dissection to a point about $\mathrm{I} \mathrm{cm}$ above the trifurcation. On the left side, an $8 \mathrm{~mm}$ long nerve gap was created by sectioning the tibial nerve. Nerve graft harvested from the right side was sutured to the tibial nerve defect with 10/0 polypropylene sutures in an end-to-end fashion.

\section{Group 2 (Vein Graft Group)}

Firstly, the animal was positioned in dorsal recumbency. A 2 $\mathrm{cm}$ ventral skin incision was made along the crease formed by the abdomen and right thigh. Blunt dissection of the adductor muscles was used to visualize the right femoral vein. A I-cm segment of the vein was resected and rinsed in saline solution. After prone positioning, the nerve gap was created as in Group I and empty vein graft was used to fill the nerve gap (Fig. Ic).

\section{Group 3 (Vein Graft SVF Combination Group)}

In this group, bilateral ventral skin incisions were made along the crease formed by the abdomen and right thigh in supine position. Inguinal fat pads were harvested and minced into I mm particles. Adipose tissue collections were aseptically extracted and placed in containers previously filled with sterile phosphate-buffered saline. The container was immediately taken to a laminar flux chamber and washed with PBS until the removal of visible blood. Clean tissue masses were sub- mitted to enzymatic digestion with collagenase (50 min, 37C) under constant shaking. After incubation, enzymatic digestion was interrupted by the addition of bovine fetal serum (BFS) (nearly 10\% of the containers' total volume). The cell suspension was then centrifuged (5 $\mathrm{min}$ at $3000 \mathrm{rpm}$ ). The supernatant (adipocyte fraction) was discarded, and the pellet containing SVF was taken into 30 gauge syringe. A $1-\mathrm{cm}$ segment of femoral vein was resected and rinsed in saline solution. After prone positioning, the nerve gap was created as in the other groups, and the vein graft was used to fill the nerve gap. In this instance, after proper coaptation, the vein grafts were filled with SVF solution (Fig. Id).

\section{Morphologic Studies}

After twelve weeks, all rats were anesthetized, and their experimental sites were explored to take specimens for histologic evaluation. Specimens including the tibial nerve from $5 \mathrm{~mm}$ distal and proximal of the suture lines were taken. Proximal part was tagged with a microsuture. After fixation and tissue processing, specimens of all groups were stained with Toluidine blue and observed with a photomicroscope to determine the total number of myelinated nerve fibers, and fiber diameter andmyelin thickness were also assessed.

\section{Statistical Analysis}

Sample size estimation was done using the Wilcoxon (MannWhitney) rank-sum test for ordered categories with a 0.05 two-sided significance level. Compliance of the quantitative data with normal distribution was analyzed by KolmogorovSmirnov test. Independent samples t test was used in the comparison of normally distributed data between the groups
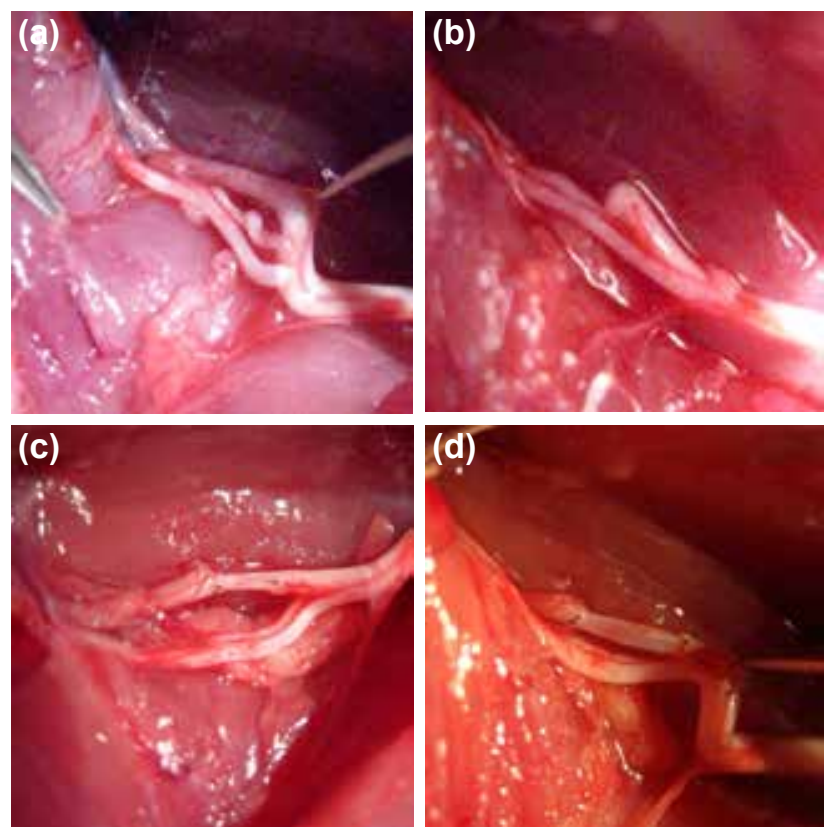

Figure 1. Intraoperative views. (a) Trifurcation of the sciatic nerve. (b) Preparation of the nerve defect, (c) repair of the defect with empty vein graft, (d) repair of the defect with vein graft filled with stromal vascular fraction. 
and descriptive statistics were displayed in the form of mean \pm standard deviation. Mann Whitney $U$ test was used in nonnormally distributed data. P-value of $<0.05$ was considered statistically significant.

\section{RESULTS}

Mean numbers of myelinated fibers of all groups are shown in Table I. The differences between Group I (nerve graft group) and Group III (SVF group) were not statistically significant ( $p>0.05$ ); however, the differences between Group II (vein graft group) and other groups (Group I, Group III) were statistically significant $(p<0.05)$.

Mean fiber diameters of all groups are shown in Table 2. The differences of the groups were not statistically significant $(p>0.05)$.

Mean myelin thicknesses of all groups are shown in Table 3. The differences of the groups were not statistically significant $(p>0.05)$.

Histologic evaluation of the transverse semithin sections from the graft revealed myelinated nerves that crossed the

Table I. Number of myelinated axons

\begin{tabular}{llll}
\hline & Mean \pm SD & Min. & Max. \\
\hline Grouplnervegraft & $2203 \pm 197$ & 1921 & 2496 \\
Groupllveingraft & $1974 \pm 216$ & 1642 & 2342 \\
Group III SVF+veingraft & $2044 \pm 163$ & 1753 & 2352 \\
\hline
\end{tabular}

Between Group I-II, Group II-III $p<0.05$, between Group I-III p $>0.05$. SVF: Stromal vascular fraction.

Table 2. Mean axonal diameter

\begin{tabular}{lccc}
\hline & Mean \pm SD & Min. & Max. \\
\hline Grouplnervegraft & $8.6 \pm 1.34$ & 7 & 10 \\
Groupllveingraft & $8.2 \pm 1.47$ & 6 & 10 \\
Group III SVF+veingraft & $8 \pm 1.24$ & 7 & 10 \\
\hline
\end{tabular}

Between Group II-III, Group I-III and Group I-II p>0.05. SVF: Stromal vascular fraction.

Table 3. Mean myelin thickness

\begin{tabular}{lccc}
\hline & Mean \pm SD & Min. & Max. \\
\hline Grouplnervegraft & $1.62 \pm 0.14$ & 1.49 & 1.86 \\
Groupllveingraft & $1.45 \pm 0.11$ & 1.24 & 1.57 \\
Group III SVF+veingraft & $1.47 \pm 0.19$ & 1.25 & 1.80 \\
\hline
\end{tabular}

Between Group II-III, Group I-III and Group I-II p>0.05. SVF: Stromal vascular fraction.
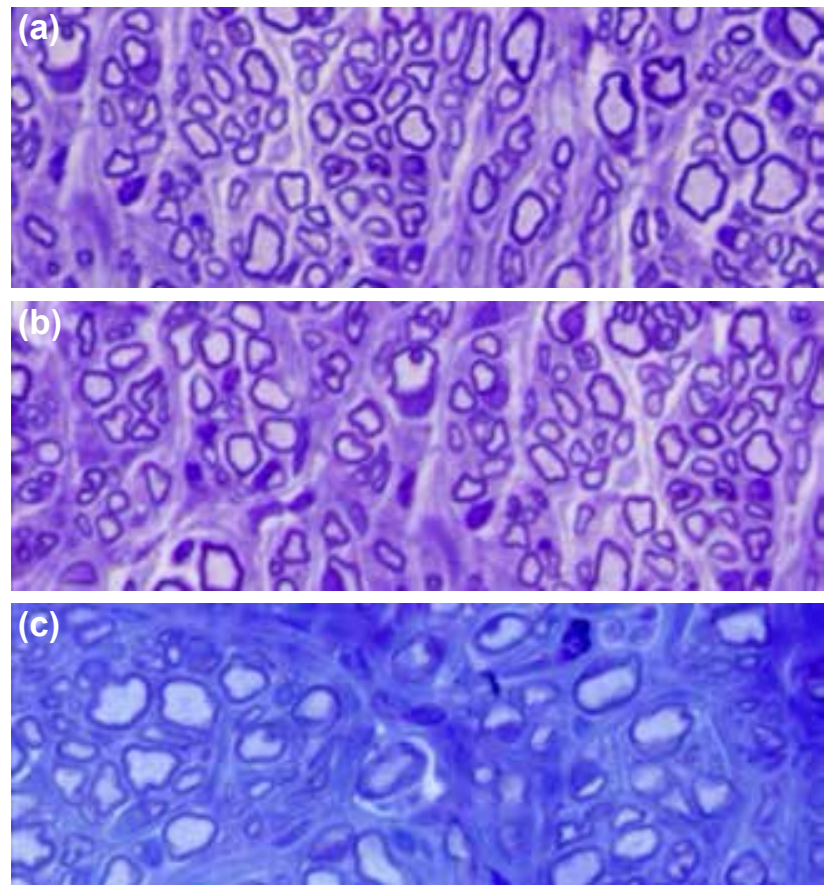

Figure 2. Histologic views. (a) Regular myelinated fibrils in many diameters and reaching vascularization were also found in nerve group, (b) more regular myelinated fibrils in larger diameters and rich vascularization were found in the study group, (c) vein group revealed untidy nerve organization engulfed in heavy fibrosis.

graft and reached the distal nerve stump in Group III (stem cell vein group). Moreover, regular myelinated fibrils in many diameters and reaching vascularization were also found in Group III (Fig. 2a). In Group I (nerve group), more regular myelinated fibrils in larger diameters and rich vascularization were found (Fig. 2b). In contrast, Group II (vein group) revealed poor vascularization and untidy nerve organization with a few nerve fibrils engulfed in heavy fibrosis (Fig. 2c).

\section{DISCUSSION}

Autograft is the golden standard for peripheral nerve defect repair, which provides continuityof the stumps with minimal or no tension and supports axonal regeneration while protecting against sourrounding scar formation.

Although the results are satisfactory, autogenous nerve grafting causes significant donor site morbidity such as scarring, neuroma formation, and loss of sensation. Therefore, alternative methods such as arterial grafts, vein grafts, and artificial tubes have been implemented with variable success rates. ${ }^{[3,9]}$

Various studies have shown that nerve guidance tubes alone cannot efficiently promote regeneration of a peripheral nerve over a gap longer than $3 \mathrm{~cm}$ in length in humans. ${ }^{[2]}$ However, incorporation of schwann cells into the tube has significantly improved the conduits performance in animal studies, but isolation of schwann cells is troublesome and causes additional morbidity. ${ }^{[6]}$ Stem cells and progenitor cells are seen 
as attractive alternatives to the use of autogeneous schwann cells. Furthermore, in various studies, stem cells aid regeneration by the release of soluble nerve growth factors such as brain derived naurotrophic factor or angiogenic molecules including vascular endothelial growth factor. Other studies have shown that stem cells can physically engraft and myelinate regenerating axons. ${ }^{[12-14]}$

Concerning the above facts, we analyzed the success of vein grafts filled with adipose derived stem cell containing stromal vascular fraction solution as a nerve guide to repair peripheral nerve defect. The regeneration achieved with empty vein graft, nerve graft and adipose derived stem cell filled vein graft was compared. First, it was found thatall conduits supported axonal regeneration without collapsing and retained a lumen providing a permissive environment for regeneration.

The best regenerative values were found with nerve grafts, which is paralel with the current literature. ${ }^{[15,16]}$ The number of myelinated fibers in the stromal vascular fraction group were statistically better than the empty vein group. Thus, it can be said thatstromal vascular fraction filled vein graft is more effective than empty vein graft, and it can be used in the repair of nerve defects in the lack of autologous nerve graft.

Many studies in the literature have shown effectiveness of cultured adipose derived stem cells in peripheral nerve regeneration. In this study, cultured stem cells were nor used to mimic the classic unexpected clinical situation in which due to lack of adequate nerve graft, vein grafts are used. It is our belief that in clinical settings, especially for large nerve defects, vein grafts filled with adipose tissue derived stem cells might be used to aid regeneration and prevent collapse, but whenever possible, nerve graft application must still be the procedure of choice.

There were some limitations and weaknesses of the experimental model in this study. Owing tothe relatively small diameter of the tibial nerve, effects of the collapse phenomenon could be masked, which may also benefit from filling of the vein lumen. In addition, tracking of florescein labeled cells and performing electrophysiological analysis, which were not available in our facility, may further enlighten the effectiveness of the procedure.

As a conclusion, the adipose tisssue derived stem cell filled vein graft is not as effective as the nerve graft, but it has better results when compared with empty vein grafts. Further experimental studies should be performed before clinical practice.
Conflict of interest: None declared.

\section{REFERENCES}

1. Balwierz A, Czech U, Polus A, Filipkowski RK, Mioduszewska B, Proszynski $T$, et al. Human adipose tissue stromal vascular fraction cells differentiate depending on distinct types of media. Cell Prolif 2008;41:44159.

2. di Summa PG, Kingham PJ, Raffoul W, Wiberg M, Terenghi G, Kalbermatten DF. Adipose-derived stem cells enhance peripheral nerve regeneration. J Plast Reconstr Aesthet Surg 2010;63:1544-52.

3. Chiu DTW, Janecka I, Krizek T. Autogenous vein graft as a conduit for nerve regeneration. Surg Forum 1980;31:550.

4. Chiu DT, Strauch B. A prospective clinical evaluation of autogenous vein grafts used as a nerve conduit for distal sensory nerve defects of $3 \mathrm{~cm}$ or less. Plast Reconstr Surg 1990;86:928-34.

5. Davis GE, Blaker SN, Engvall E, Varon S, Manthorpe M, Gage FH. Human amnion membrane serves as a substratum for growing axons in vitro and in vivo. Science 1987;236:1106-9.

6. Enver MK, Hall SM. Are Schwann cells essential for axonal regeneration into muscle autografts? Neuropathol Appl Neurobiol 1994;20:587-98.

7. Kong JM, Zhong SZ, Bo S, Zhu SX. Experimental study of bridging the peripheral nerve gap with skeletal muscle. Microsurgery 1986;7(4):1839.

8. Mackinnon SE, Dellon AL, Hudson AR, Hunter DA. Nerve regeneration through a pseudosynovial sheath in a primate model. Plast Reconstr Surg 1985;75:833-41.

9. Mohammad J, Shenaq J, Rabinovsky E, Shenaq S. Modulation of peripheral nerve regeneration: a tissue-engineering approach. The role of amnion tube nerve conduit across a 1-centimeter nerve gap. Plast Reconstr Surg 2000;105:660-6.

10. Santiago LY, Clavijo-Alvarez J, Brayfield C, Rubin JP, Marra KG. Delivery of adipose-derived precursor cells for peripheral nerve repair. Cell Transplant 2009;18:145-58.

11. Rigotti G, Marchi A, Galiè M, Baroni G, Benati D, Krampera M, et al. Clinical treatment of radiotherapy tissue damage by lipoaspirate transplant: a healing process mediated by adipose-derived adult stem cells. Plast Reconstr Surg 2007;119:1409-24.

12. Ryu HH, Lim JH, Byeon YE, Park JR, Seo MS, Lee YW, et al. Functional recovery and neural differentiation after transplantation of allogenic adipose-derived stem cells in a canine model of acute spinal cord injury.J Vet Sci 2009;10:273-84

13. Terzis JK, Sun DD, Thanos PK. Historical and basic science review: past, present, and future of nerve repair. J Reconstr Microsurg 1997;13:21525.

14. Yavuzer R, Ayhan S, Latifoğlu O, Atabay K. Turnover epineural sheath tube in primary repair of peripheral nerves. Ann Plast Surg 2002;48:392400.

15. Zuk PA, Zhu M, Ashjian P, De Ugarte DA, Huang JI, Mizuno H, et al. Human adipose tissue is a source of multipotent stem cells. Mol Biol Cell 2002;13:4279-95.

16. Savran M, Bekar A, Cansev M, Tolunay S, Ulus IH, Taskapilioglu MO. Prevention of epidural fibrosis in rats by local or systemic administration of citicoline. Turk Neurosurg 2012;22:634-40. 
DENEYSEL ÇALIŞMA - ÖZET

\section{Yağ dokusundan elde edilmiş stromal vasküler fraksiyonla doldurulmuş ven greftleri ile periferik sinir kayıplarının onarımı: Deneysel çalışma

\author{
Dr. Heval Selman Özkan, ${ }^{1}$ Dr. Özlem Karataş Silistreli, ${ }^{2}$ Dr. Bekir Ergür, ${ }^{3}$ Dr. Saime İrkoren ${ }^{1}$
}

${ }^{1}$ Adnan Menderes Üniversitesi Tıp Fakültesi, Plastik ve Rekonstrüktif Cerrahi Anabilim Dalı, Aydın
${ }^{2}$ Izmir Ataturk Egitim ve Araştırma Hastanesi, Plastik ve Rekonstrüktif Cerrahi Kliniği, İzmir

${ }^{3}$ Dokuz Eylül Üniversitesi Tıp Fakültesi, Histoloji Embiroloji Anabilim Dalı, İzmir

AMAÇ: Periferik sinir defektlerinin onarımda ven greftleri ile beraber hücre kültürleri kullanımı çalışmaları literatürde bulunmaktadır. Yağ dokusu kaynaklı kök hücrelerin periferik sinir iyileşmesini artırdığını gösteren çalışmalar literatürde bulunmaktadır. Bu nedenlerle periferik sinir defekti onarımlarında ven grefti ve yağ dokusu kaynaklı kök hücre kombine olarak kullanımı etkilerini değerlendirmek amacı ile sıçanlarda deneysel çalışma uyguladık.

GEREÇ VE YÖNTEM: Bunun için yaklaşık 300 gr ağırlı̆̆ında 30 adet Wistar albino cinsi sıçan üç çalışma grubuna ayrıldı. Birinci cerrahi basamakta tüm hayvanların sağ tibial sinirlerinde yaklaşık $8 \mathrm{~mm}$ sinir defekti oluşturuldu. Grup I'de (I0 hayvan) otojensinir grefti kullanıldı. Grup 2'de (I0 hayvan) içi boş ven grefti ile, Grup 3'de ( 10 hayvan) ise ven grefti içine yağ dokusu kaynaklı kök hücre doldurularak onarım uygulandı. Bu işlemden üç ay sonra çalışmanın ikinci cerrahi basamağında hayvanlar sakrifiye edilerek onarım uygulanan sinir bölgesinden biyopsi alındı. Alınan örnekler ışık mikroskobu ile histopatolojik olarak değerlendirildi.

BULGULAR: İstatistiksel olarak gruplar arasında miyelin ve akson çapı arasında anlamlı farklar yokken, akson sayısı açısından anlamlı farklar mevcuttu. TARTIŞMA: Sonuçlarımıza göre periferik sinir kayıplarının onarımında SVF ve ven grefti kombinasyonu uygulanabilir bir seçenektir.

Anahtar sözcükler: Adipoz doku; sinir defekti; stromal vasküler fraksiyon; ven greft.

Ulus Travma Acil Cerrahi Derg 2016;22(I):7-II doi: 10.5505/tjtes.2015.126I2 